\title{
The Voices of Young Sexual Offenders in Norway: A Qualitative Study
}

\author{
Marita Sandvik ${ }^{1}$ Merete Berg Nesset ${ }^{1,2}$, Anita Berg ${ }^{3}$, Erik Søndenaa ${ }^{1,4}$ \\ ${ }^{1}$ Forensic Department, St. Olavs University Hospital, Trondheim, Norway \\ ${ }^{2}$ Department of Neuroscience, Faculty of Medicine, Norwegian University of Science and Technology, Trondheim, Norway \\ ${ }^{3}$ Faculty of Health Science, Nord University, Namsos, Norway \\ ${ }^{4}$ Department of Mental Health, Regional Centre for Child and Youth Mental Health and Child Welfare, Faculty of Medicine, \\ Norwegian University of Science and Technology, Trondheim, Norway \\ Email: marita.sandvik@stolav.no
}

How to cite this paper: Sandvik, M., Nesset, M.B., Berg, A. and Søndenaa, E. (2017) The Voices of Young Sexual Offenders in Norway: A Qualitative Study. Open Journal of Social Sciences, 5, 82-95.

https://doi.org/10.4236/jss.2017.52009

Received: January 16, 2017

Accepted: February 5, 2017

Published: February 8, 2017

Copyright (c) 2017 by authors and Scientific Research Publishing Inc. This work is licensed under the Creative Commons Attribution International License (CC BY 4.0).

http://creativecommons.org/licenses/by/4.0/

\begin{abstract}
Adolescents commit around 20 - 30 percent of all sexual offences and attempts have been made in the literature to distinguish between types of young sexual offenders. This study describes the understanding of nine Norwegian young male sexual offenders regarding sexual offences committed by them during adolescence, their childhood experiences and their suggestions on how to prevent juvenile sexual offending. The participants were interviewed with individual, semi-structured interviews and the rich data were analyzed with systematic text condensation. The young offenders' understanding of mutuality in the relationship with their minor victim contributed to the sexual offence. Moreover, moral immaturity, learning difficulties or being a refugee, exposure to child pornography, impulsivity and high sexual arousal were described as having impacted on their offending. Findings suggest the need for further studies to understand the risk factors for juvenile sexual offending. Better knowledge about the legal framework of a sexual relationship and consequences of sexual abuse for both offenders and victims were highlighted to be the most important measure to prevent sexual abuse by juveniles in general.
\end{abstract}

\section{Keywords}

Young Adult Sexual Offenders, Juvenile Sex Offender, Vulnerabilities, Cognitive Distortions, Qualitative Research

\section{Introduction}

Sexual violence is a significant health and social problem worldwide [1] [2] [3]. Being sexually victimized is associated with a large number of physical and psy- 
chological problems [4] [5] [6], and is related to the later risk of sexual offending in juveniles [7] [8] [9]. Existing adult offender treatment programmes show limited effectiveness regarding relapse prevention [10] [11] [12]. This indicates a need to further study possible causes of sexual offences in depth in order to target offender interventions.

Sexually abusive behavior is defined as any sexual interaction with persons of any age that is perpetrated: a) against the victim's will, b) without consent, or c) in an aggressive, exploitative, or manipulative manner [13]. Molestation may involve touching, rubbing, sucking, exposure to sexual materials, or sexual penetration. The legal definition of sexual assault in Norway is stated in the Norwegian Penal Code (2002): "Sexually offensive or obscene behavior, and sexual acts or intercourse with children" (first author's translation). According to the law, the age of consent for engaging in sexual relationships is 16 years, and it is considered aggravated sexual assault if the child is under the age of 14 .

Nordic studies of adolescents have shown that the majority of the adolescent sexual offenders are males with the majority of the victims being young females in their early teens [14] [15] [16]. Moreover, international studies show that adolescent males have been responsible for approximately 20 - 30 percent of sexual assaults, and 50 percent of adult sexual offenders report deviant sexual interests from early adolescence [4] [17]. About 15 percent of juvenile sexual offenders reoffend within an average of five years [14] [18] [19] [20]. Deviant sexual preferences and antisocial orientation are described as major predictors of sexual recidivism for both adult and adolescent sexual offenders [21].

In Norway in 2013, 156 male adolescents (13 - 17 years old) and 225 young male adults (18 - 20 years old) were charged with one or more sexual offences, which included about 17 percent of all charged sexual assaults [22]. The real prevalence of sexual offences among juveniles is difficult to estimate due to under-reporting, taboos, the victim's feelings of guilt and shame, and the fact that most of the abuse is committed by friends and trusted people [4] [13] [17] [23].

Adolescent sexual offenders are varied in terms of internal and external characteristics [24] [25]. Some studies have indicated that the same risk factors are found among sexual offenders and non-sexual offenders: poor attachment to family and school, poorer attachment between parent and adolescent, and lower parental involvement [26] [27], although a recent meta-analysis could not find support for these factors as related to adolescent sexual offending [28]. A study of 4000 Swedish and Norwegian male high school students found that young people who had experienced sexual coercion were approximately three times more likely to engage in sexually coercive behaviour than those without such experiences [28]. In addition, between 30 - 70 percent of adolescent sexual offenders are victims of sexual abuse [4] [14]. Low self-esteem, emotional loneliness, anxiety and social isolation, greater deviant sexual preferences like sexual arousal towards children, and problems with emotional regulation and cognitive distortions have been reported among adult and adolescent sexual offenders [28] [29] [30]. While some studies have indicated that sexual offenders (who offend 
against children) are lower in intelligence than non-sexual offenders [31], others have not been able to find evidence for either over-representation or under-representation of clients with intellectual disabilities among sex offenders [28] [32].

Few studies have presented the views of juveniles and young adult sexual offenders. The aim of this study was to explore sexual offenders' reflections on their offence committed during adolescence concerning their childhood and adolescent experiences. A further focus was to capture their own ideas of preventing sexual offences committed by juveniles.

\section{Methods}

\subsection{Design and Participants}

This was a qualitative study involving juveniles and young adult sexual offenders. The participants were recruited from the Norwegian Correctional Service, and were eligible for this study if they were of at least 15 years of age and had been sentenced or charged with sexual crimes before the age of 20 . The final sample consisted of nine participants, all men, aged $16-25$ years with an average age of 19 years. Four were ethnic Norwegians; one was adopted, and four were refugees from African countries. All of the informants were convicted of sexual offences against minors under the age of 14 .

\subsection{Data Collection}

The participants were interviewed individually in a semi-structured manner. Semi-structured interviews were chosen in order to allow the informants the freedom to express their stories in their own terms but still in a planned way. An interview guide was developed with input from five main topic areas: a) background/history, b) family relations, c) self-esteem, d) own understanding of the offence, e) thoughts about preventing sexual offences among juveniles. When preparing the interview guide, validated questions about self-esteem from the Adolescent Sexual Abuser Protocol [33] were included.

The data were collected between June and November 2013. The informants received verbal information and an information sheet from their probation of ficer in the correctional service inviting them to participate in the study, and signed a consent form before taking part in the study. The interviews were conducted in various settings depending on the informants' preferences: the informant's home, in prison, in interview rooms at police stations and at Correctional Service locations. The interviews ranged from 45 to 90 minutes in length. All interviews were audiotaped and transcribed verbatim by the first author. The quotes in the result section were translated into English by the first author and verified by the author group.

\subsection{Data Analysis}

The transcribed manuscripts were analyzed with systematic text condensation, a general cross-case method for thematic analysis of qualitative data [34]. The 
analysis consisted of four steps: 1) Reading all the material to get an overall impression of preliminary themes; 2) Identifying semantic units in the text, i.e., units representing a single aspect of the participants' relevant experience, and coding them into code groups; 3 ) Clarifying different aspects within the code group, dividing each code group into sub groups from which condensates were developed and illustrative quotations were identified, and 4) Descriptions of participants' experiences were extracted. The author group discussed themes, code groups and final categories throughout the analysis process.

\subsection{Ethical Considerations}

The study was approved by the Norwegian Data Inspectorate (NSD) and the Correctional Service. The participants were informed of limits to confidentiality. All participants were given the opportunity to make contact with the first author or their officer in the Correctional Service after the interview. They did not receive any compensation for participating.

\section{Results}

The young sexual offenders in this study were heterogeneous with regard to background and childhood experiences. An overview of the informants' background characteristics is provided in Table 1.

All informants were charged with or sentenced for sexual offending against a

Table 1. Background characteristics of the informant sample.

\begin{tabular}{|c|c|c|c|c|c|c|c|c|c|}
\hline & 1 & 2 & 3 & 4 & 5 & 6 & 7 & 8 & 9 \\
\hline Birth year & 1992 & 1992 & 1994 & 1996 & 1993 & 1995 & 1988 & 1995 & 1994 \\
\hline $\begin{array}{l}\text { Childhood } \\
\text { environment }\end{array}$ & $\begin{array}{l}\text { Family/ } \\
\text { Institution }\end{array}$ & $\begin{array}{l}\text { Adoptive family/ } \\
\text { Institution }\end{array}$ & Family & Family & Family & Family & Family & Family & Family \\
\hline Siblings & 3 & 1 & 2 & 3 & 11 & 3 & 4 & 1 & 2 \\
\hline $\begin{array}{l}\text { Mental health } \\
\text { disorders }\end{array}$ & $\begin{array}{l}\text { ADHD } \\
\text { Substance } \\
\text { abuse }\end{array}$ & $\begin{array}{l}\text { ADHD } \\
\text { LD }\end{array}$ & & & & & $\begin{array}{l}\text { ADHD-sympt. } \\
\text { Depression } \\
\text { LD }\end{array}$ & $\begin{array}{l}\text { Depression } \\
\text { Anxiety }\end{array}$ & $\begin{array}{l}\text { Depressive } \\
\text { episode }\end{array}$ \\
\hline Age at offence & 17 & 18 & 18 & 16 & 16 & 17 & 18 & 16 & 16 \\
\hline $\begin{array}{l}\text { Relation to victim } \\
\text { (age) }\end{array}$ & Stranger (13) & $\begin{array}{l}\text { 1. Stranger (5) } \\
\text { 2. Known }(10)\end{array}$ & Known (13) & Known (13) & $\begin{array}{c}\text { Prior } \\
\text { girl-friend (13) }\end{array}$ & $\begin{array}{c}\text { Prior } \\
\text { girl-friend (13) }\end{array}$ & Friend (13) & Known (9) & Girlfriend (13) \\
\hline Behaviour problems & Yes & Yes & No & No & No & No & Yes & No & No \\
\hline $\begin{array}{l}\text { Childhood } \\
\text { trauma/neglect }\end{array}$ & No & $?$ & No & No & No & No & No & No & No \\
\hline Adverse experiences & $\begin{array}{l}\text { Father died } \\
\text { Schoolprob. } \\
\text { Stepfather's } \\
\text { suicide }\end{array}$ & $\begin{array}{c}\text { Bullying } \\
\text { in school \& } \\
\text { neighbourhood }\end{array}$ & Refugee & Refugee & $\begin{array}{c}\text { Refugee } \\
\text { Father } \\
\text { disappeared }\end{array}$ & $\begin{array}{c}\text { Refugee } \\
\text { Father } \\
\text { disappeared }\end{array}$ & $\begin{array}{l}\text { Bad relationship } \\
\text { to father } \\
\text { Schoolprob. } \\
\text { Bullying }\end{array}$ & $\begin{array}{c}\text { Bullying/ } \\
\text { exclusion from } \\
\text { friends } \\
\text { Parents' } \\
\text { divorce }\end{array}$ & $\begin{array}{l}\text { Parents' } \\
\text { divorce }\end{array}$ \\
\hline
\end{tabular}


minor under the age of 14 . The mean age of the victims was 11.5 (range: 5 - 13). In seven of the cases, the victims were females and in two cases males. Two of the informants were convicted of one episode of sexual abuse, one with diversity of victims and types of offences, while the others had several episodes of abuse against the same victim. For two of the informants, the abuse occurred across several years. None of the informants reported alcohol or drug abuse in adolescence or being intoxicated during their offending.

\subsection{Reciprocity and Mutuality}

All the informants who admitted their offence mentioned the offending as being a consensual sexual activity. The majority described their sexual offending as a result of non-abusive activities in the confines of a dating relationship with the minor. This was represented by statements like: "The girl was my girlfriend and we both wanted sex. I had heard from friends that sex was okay if both wanted it, and I didn't think about her age...”

Another one shared: "The girl was my friend and my girlfriend for a period of one month. I knew she was only 12 years old, but she looked older and was very physically mature, so I thought everything was okay."

Several explained the sexual offending as a mutual activity between two consenting parties and claimed that the victim initiated sex by inviting them to dates and buying contraception: "The girl was a prior girlfriend of my friend. She was inviting me to have sex with her, and I thought this was okay because she wanted this just as much as me. She even bought me condoms." These behaviors, as well as physical appearance (being tall and having a mature body), were reported as being the causes of their assumption that the sexual activity was consensual and legal.

Some of the participants described the offence as a mutual exploration of sexuality and sexual curiosity: "I had a sexual relationship with a 13 year old boy. He was curious and I was curious and then it became like this... I thought this was all right because he participated in the sexual activities. I was thinking about the relationship as equal and that we were having normal sexual activities."

Another informant shared: "I had one episode of sexual activity with a minor boy at the age of 9 . We were hiding behind some hay at a farm and decided together to do the sexual activities I now have been sentenced for. This was okay for him, and I was thinking about this as play and a normal exploration of sexuality. I did nothing against his will."

None of the informants who admitted their offence thought about it as an offence because they did not use threats, power or any force to get the minor to participate. They all claimed that this type of offence should be named "illegal sexual activities against minors," rather than sexual violence and offence. Due to the current wording, all of the perpetrators were afraid of being stigmatized as rapists or child molesters.

\subsection{Lack of Knowledge and Understandings}

Lack of knowledge or understanding about the age of consent and the distinc- 
tion between illegal and legal sex were central explanations for many of the participants. This view was represented by statements like: "I didn't know this was called an offence because I had never heard about the age of consent", "I thought everything was legal as long as the girl wanted this herself" and: "I didn't have any teaching about sexual issues and laws at school, I didn't understand the difference between illegal and legal sexual activities."

Physical characteristics like being tall and having a mature body were reported as being the causes of their assumption that the victim was old enough.

Attitudes to the age of consent and cultural explanations of sexual relationships were also raised by several of the participants: "In my hometown sex with a minor girl at the age of 13 is as common as buying apples at the store. It feels unfair that I have a conviction for this and not my mates." One of the refugees stated: "Where I come from, girls can be married at the age of 13."

\subsection{Impulsivity and Strong Sexual Arousal}

The majority of the participants described high sexual arousal and impulsivity as triggers and the main causes of the offence: "The abuse of a five year old girl came suddenly 'like lightning" and: "...I just wanted her so much and think my hormones and physical needs took control of my brain."

All of the participants who admitted their offence also admitted to being sexually attracted or aroused by their victims. In two cases, this revealed itself in declarations of love for the victim.

Two of the informants reported the use of pornography as a trigger for their strong sexual arousal. These two reported significant use of the internet to seek out information about sex and look for pornography and sexualized pictures of children. One of them said: "I was curious about everything about sex at that time and spent a lot of time seeking pornography on the internet." The other stated his use of the internet as a possible cause of his offence: "Maybe someone at that time should have checked my use of pornography... I got a lot of strange sexual thoughts and fantasies." One informant was also sexually aroused by downloaded pictures of children being sexually abused.

\subsection{Adverse Experiences in Childhood and Adolescence}

When asked about trauma in childhood including: "have you ever experienced physical or sexual abuse?" and "have you ever experienced not getting enough food, clothing and love/care from your parents?" none of the informants reported early trauma or neglect in their childhood. Some of their comments included "I have always been fine at home," and "My parents have always been supportive" However, when asked "what kind of difficulties have you experienced during childhood and adolescence?," many described severe problems outside of their parental home, including learning difficulties at school, maladjustment, mental health/psychological problems, war experiences, bullying, and exclusion from friends. They highlighted being different and having problems with being accepted and fitting in with peers: "To be accepted in my school, you 
had to be similar to the others-play football and such things. I was different with other interests, and after I disclosed being bisexual, I got banned from all my prior friends." The refugees told about experiences related to war and escape like: "We lived in tents and had to look after our food all the time, otherwise the food was stolen" and: "My father disappeared and we didn't know if he was dead or alive."

Two of the respondents talked about having poor self-esteem almost their whole lives; one since he started school and the other since he became excluded from his friends at the age of $12-13$. These two said that they developed symptoms of depression at the age of $12-13$ and were diagnosed in adolescence. They were still struggling with their self-esteem and thoughts of being worthless, with statements like: "Some days I feel all right and have positive thoughts about myself and the future. Other days, I feel completely miserable..." and: "Some [people] are just not worthy to be on earth."

The trial was a difficult time with a lot of shame, embarrassment and fear for those who admitted their offence, and they reported their self-esteem as very low during the criminal procedures. They all described feelings of guilt and shame related to their acts, victim and families on both sides. One of them summarized: "This case is the worst that has ever happened me-I didn't like myself at all for a long period."

\subsection{Preventing Recidivism and Juvenile Sexual Offending}

With statements like: "I am sure I have good chances to succeed" and "I can do everything I want", the majority showed a high level of belief about their future with education, employment and having a family. Only one had no faith in own success and believed everything would continue to be difficult and unsuccessful in the future. When talking about prevention of sexual offences, all reported a high confidence level about not committing further offences. They all justified their confidence by their experiences during the criminal process as well as their contact with the Correctional Criminal Service officers. They claimed that they had learned "the hard way" through the consequences of their actions, as well as through their psychological maturation since the time of the offence.

The majority of the participants believed that better knowledge about sexual abuse, intimacy issues, the sexual age of consent, as well as consequences for both themselves and the minors, could have prevented their own offending. They highlighted education to be the most important measure to prevent sexual abuse by juveniles in general: "Teaching about sexuality, abuse and the consequences of being abused or committing sexual offending is the most important. This theme should have been repeated several times in different classes in school because puberty, when this issue will be relevant, comes at different times."

Several of the non-ethnic Norwegian participants were concerned about knowledge about sex, rules and laws in Norway. As one of them stated: "It is important that all juveniles, but especially juveniles coming from other countries, get information and learn about sex and rules and laws about sex, age and 
so on." Especially the legal age was highlighted: "Focusing on the age of sexual consent-that's the most important."

One of the informants who told about his use of pornography as a possible cause of his own offending proposed stricter controls of internet activities: "Maybe this is a wrong way of doing it... but maybe closing pornography sites on the Internet should have been done to prevent fantasies about deviant sexuality. You adults can never imagine what juveniles are looking at."

\section{Discussion}

The aim of this study was to explore Norwegian young sexual offenders' reflections on their offence committed during adolescence, their childhood and adolescent experiences, and their suggestions on how to prevent juveniles from committing sexual offences.

None of the informants considered themselves as sexual offenders, even if eight admitted to sexual acts against minors. All described their own offence as consensual and mutual with a partner or friend, and reported no concerns about the victim's age at the time of the offence. Even though admitting the sexual offence, they did not look upon themselves as sexual offenders, due to the lack of force or coercion against the victims. The victims were, in most of the cases, defined as girlfriends, former or potential girlfriends or friends at the time of the offence, which is in line with earlier research on sexual offenders [4] [13] [17] [23]. Juvenile sexual assaults may be a result of sexual experimentation rather than a sexual deviance [35]. Although engaging in sexually deviant behavior, the majority of juvenile sexual offenders appear not to experience persistent or entrenched sexual deviance [36].

Research has highlighted the importance of addressing distorted cognitions and thinking errors in the assessment and treatment of sexual offenders [18] [37] [38] [39]. The nature of cognitive distortions has been identified as both giving the offender permission to offend and make him or her feel better about the offence by justifying, excusing or externalizing blame to others, thereby minimizing self-blame and guilt [30] [39] [40]. In our study, the informants described their offence as "consensual and mutual". These cognitive distortions both act as permission-giving for their sexual offence and as a way to deal with their difficult feelings such as blame and guilt during the trial. Use of cognitive distortions may also limit the trauma of being categorized as a "sexual offender". This label may be challenging for persons committing sexual offences, and the stereotypical pictures of sexual offenders as egoistic and evil encourage distancing, avoidance and minimization [4].

The informants did not describe or report about early childhood traumatization of exposure to violence, abuse or neglect, a finding supported by Seto and Lalumière's (2010) [28] findings, as well as by the findings in Nøttestad, Bjørngaard \& Rasmussen's (2010) [41] study of sexual offenders in a Norwegian prison population. The latter study found that the Norwegian sample of sexual offenders had a significantly better background in terms of employment, family 
attachment and living conditions when compared to non-sexual offenders. However, in our study there were rich descriptions of negative experiences like being a refugee, being bullied at school, exclusions from friendships and experiencing learning difficulties, which may have had significant influence on personality, emotional regulation and use of cognitive distortions. Exposure to traumatic stress in early life is associated with enduring sequelae such as self-regulatory, self-regulatory, attachment, anxiety, and affective disorders in infancy and childhood, aggression, dissociative disorders and sexual disorders in adolescence and adulthood [42].

Everyone reported good attachment to one or both of their parents in childhood, and eight still felt very close to their parents. It is worth noting that eight out of nine informants emphasized their mother as being the most important person in their lives, both during childhood and young adulthood, in contrast to what is found in previous studies on young sexual offenders' attachment to parents [4] [14] [40].

Problems with social and intimacy skills and emotional regulation are associated with sexual offending among juveniles [21] [30] [43]. Several of the informants in our study reported being diagnosed with depression, Attention Deficit/Hyperactivity Disorder (ADHD) and Learning disability (Table 1), where isolation, hopelessness, impulsivity and limited self-control were presented as problematic. Even if diagnosed mental illness are not associated with future offending among adolescent offenders [44] [45], the symptoms associated with these disorders and inability to regulate emotions may reflect vulnerabilities related to their sexual offending [4]. Mood problems can also lead to the use of sex as a coping strategy which is associated with a greater likelihood of sexual offending [4] [30] [46]. Persons with lower cognitive abilities may have poorer judgment or impulse control and thus may be more vulnerable to commit sexual offenses. They may also be more likely to be sexually rejected by peers and thus may be more likely to turn to children [31]. The increases in hormone production in puberty, in combination with the emotional and physical changes associated with this period, can provide further pressure on an already limited selfcontrol [30]. A person who already struggles emotionally and cognitively will probably be more vulnerable in coping with this phase.

The informant who described sexual arousal to children during adolescence also reported having committed several and different kinds of sexual offences during adolescence. Sexual arousal in children and antisocial attitudes has been highlighted as the strongest predictors of sexual reoffending for both adult and juvenile sexual offenders [21] [30]. Both attitudes supporting sexual assaults and sexual deviance are however difficult subjects to report in an interview setting. Moreover, many are unwilling to admit or discuss deviant sexual interests and fantasies, possibly due to wanting social desirability [30]. The unwillingness to reveal antisocial attitudes and sexual deviance challenges researchers, the Criminal Justice System and Health Care System to uncover these risk factors and give appropriate interventions. 
According to some of the informants, early exposure to pornography and sexualized pictures of children contributed to deviant thoughts and sexual arousal towards children. They recommended a greater attention and concern from caregivers and schools to juveniles' use of pornography. The availability and use of Internet pornography among adolescents have been found to be significant and common in low age groups of both genders [47]. Self-reported interest in having sex with a child is also reported to have a strong association with self-reported child pornography viewing [48]. The internet makes pornography easily accessible, affordable and anonymous, an aspect which must be taken into account when dealing with juvenile sexual offending.

\subsection{Methodological Considerations}

To explore the informants' individual experiences and thoughts we chose individual interviews, which are considered appropriate for collecting data to explore life events and social phenomena [34]. We considered the use of standardized measures to assess traumatic experiences and attachment to parents as they could have added a deeper level of support for the youths' own subjective self-report. However, we wanted the opportunity to follow-up more closely the informants' individual experiences about own vulnerabilities and explanations regarding causal factors of sexual offending. Results from British studies have indicated that youths are no more suggestible than adults, unless their answers are subjected to negative feedback [49], which adds to the reliability of the information from the interviews in our study.

Systematic text condensation may miss some of the nuances in the data. The raw data are the actual incidents and the informants' experiences of them, and when oral interviews are translated into written text, there is always a risk of distortions, even at detailed reproductions [34]. The sample in this study was small, and the informants' young ages and feelings of guilt and shame might have complicated the reporting of their feelings and thoughts about the topic. As such, the findings must be interpreted with caution.

The design of this study makes it inappropriate to make inferences about the larger population of young sexual offenders. The sample is both small and seemingly different from the general young adult sexual offender population. However, the findings could still raise questions if there are cultural differences between young Norwegian sexual offenders as compared to other countries. Also, our study adds to existing research in describing a complex phenomenon, and the findings might contribute to broadening our understanding of adolescent sexual offending.

\subsection{Clinical Implications and Future Research}

Teaching and supervision about sexuality and sexual assaults were presented as a preventive factor whether the offence was described as a consensual and mutual sexual activity or explained as a result of immaturity, high sexual arousal or little sexual knowledge and understanding. Restricted access to pornography, moni- 
toring and supervision on the use of pornography was also pointed out as important. These issues should be emphasized in further studies, and may be important factors in the prevention of sexual juvenile offences.

A greater attention should also be given to teaching and supervision about sexual issues and pornography. The education in schools, based on general principles of appropriate sexual behavior, may according to this study fail in pupils with learning disabilities, cultural minorities, deviant sexual interest, antisocial behavior and/or psychological distress. Individualized education that defines the basics of appropriate sexual behavior may be needed where the awareness of prejudices, attitudes and lack of knowledge of consensus is included.

No early trauma, neglect or poor parental-child attachment during childhood were reported in the interviews. That is not the norm according to the literature [4] [13] [26] [27]. This result could be caused by using interview as the main method for gathering information, use of self-protective mechanisms in the interview situation and retention of information. This could also mean that factors other than early trauma and insecure attachment are prominent in explaining juvenile sexual offending. The informants' stories of adverse experiences and psychological problems in childhood and adolescence make it important to conduct further studies of negative experiences in adolescence related to juvenile sexual offending.

The adolescent subcultures where sexual contact with minors appears to be more common should also be studied in more detail in order to identify a possible relationship with sexually offensive behavior.

\section{Conclusion}

Understanding the perspectives of young sexual offenders and their motivations for offending is important for developing future interventions for this group and reducing recidivism and juvenile sexual offences in general. This study of nine young men convicted of sexual offences committed during adolescence showed that there were some deficits in appropriate knowledge of mutuality in sexual relations, knowledge of what the consent to a sexual relationship means and the knowledge of the legal framework of a sexual relationship. Such deficits were partly explained by personal characteristics such as immaturity, impulsivity, high sexual arousal and learning difficulties. Another factor presented as important for committing sexual offence was ideas and fantasies after exposure to pornography and sexualized pictures of children.

\section{References}

[1] Garcia-Moreno, C. and Watts, C. (2011) Violence against Women: An Urgent Public Health Priority. Bulletin of the World Health Organization, 89, 2. https://doi.org/10.2471/BLT.10.085217

[2] Krug, E.G., et al. (2002) World Report on Violence and Health. World Health Organization, Geneva.

[3] WHO (2013) Global and Regional Estimates of Violence against Women: Prevalence and Health Effects of Intimate Partner Violence and Non-Partner Sexual 
Violence. World Health Organization.

[4] Barbaree, H.E. and Marshall, W.L. (2008) The Juvenile Sex Offender. Guilford Press.

[5] Crome, S. and McCabe, M.P. (1995) The Impact of Rape on Individual, Interpersonal, and Family Functioning. Journal of Family Studies, 1, 58-70. https://doi.org/10.5172/jfs.1.1.58

[6] Macdowall, W., et al. (2013) Lifetime Prevalence, Associated Factors, and Circumstances of Non-Volitional Sex in Women and Men in Britain: Findings from the Third National Survey of Sexual Attitudes and Lifestyles (Natsal-3). The Lancet, 382, 1845-1855. https://doi.org/10.1016/S0140-6736(13)62300-4

[7] Forsman, M., et al. (2015) Sexually Coercive Behavior Following Childhood Maltreatment. Archives of Sexual Behavior, 44, 149-156.

https://doi.org/10.1007/s10508-014-0296-0

[8] Jespersen, A.F., Lalumière, M.L. and Seto, M.C. (2009) Sexual Abuse History among Adult Sex Offenders and Non-Sex Offenders: A Meta-Analysis. Child Abuse \& Neglect, 33, 179-192. https://doi.org/10.1016/j.chiabu.2008.07.004

[9] Pears, K.C. and Capaldi, D.M. (2001) Intergenerational Transmission of Abuse: A Two-Generational Prospective Study of an At-Risk Sample. Child Abuse \& Neglect, 25, 1439-1461. https://doi.org/10.1016/S0145-2134(01)00286-1

[10] Dennis, J.A., et al. (2012) Psychological Interventions for Adults Who Have Sexually Offended or Are at Risk of Offending. Cochrane Database of Systematic Reviews, 12. https://doi.org/10.1002/14651858.cd007507.pub2

[11] Grønnerød, C., Grønnerød, J.S. and Grøndahl, P. (2015) Psychological Treatment of Sexual Offenders against Children a Meta-Analytic Review of Treatment Outcome Studies. Trauma, Violence, \& Abuse, 16, 280-290.

https://doi.org/10.1177/1524838014526043

[12] Långström, N., et al. (2013) Preventing Sexual Abusers of Children from Reoffending: Systematic Review of Medical and Psychological Interventions. BMJ, 347, f4630.

[13] Ryan, G., Leversee, T.F. and Lane, S. (2011) Juvenile Sexual Offending: Causes, Consequences, and Correction. John Wiley \& Sons, Hoboken.

[14] Långström, N. and Grann, M. (2000) Risk for Criminal Recidivism among Young Sex Offenders. Journal of Interpersonal Violence, 15, 855-871. https://doi.org/10.1177/088626000015008005

[15] Mossige, S., et al. (2010) The Prevalence of Sexual Offences and Abuse within a Norwegian Youth Population. Norsk Epidemiologi, 20, 53-62.

[16] Seto, M., et al., (2010) Sexual Coercion Experience and Sexually Coercive Behavior: A Population Study of Swedish and Norwegian Male Youth. Child Maltreatment, 15, 219-228. https://doi.org/10.1177/1077559510367937

[17] Finkelhor, D., Ormrod, R. and Chaffin, M. (2009) Juveniles Who Commit Sex Offenses Against Minors. Juvenile Justice Bulletin. https://doi.org/10.1037/e630532009-001

[18] Beech, A.R., Fisher D.D. and Thornton D. (2003) Risk Assessment of Sex Offenders. Professional Psychology: Research and Practice, 34, 339-352. https://doi.org/10.1037/0735-7028.34.4.339

[19] Caldwell, M.F. (2002) What We Do Not Know about Juvenile Sexual Reoffense Risk. Child maltreatment, 7, 291-302. https://doi.org/10.1177/107755902237260

[20] Worling, J.R. and Langstrom, N. (2006) Risk of Sexual Recidivism in Adolescents Who Offend Sexually. The Juvenile Sex Offender.

[21] Hanson, R.K. and Morton-Bourgon, K.E. (2005) The Characteristics of Persistent 
Sexual Offenders: A Meta-Analysis of Recidivism Studies. Journal of Consulting and Clinical Psychology, 73, 1154. https://doi.org/10.1037/0022-006X.73.6.1154

[22] National Statistics (2012) Siktelser mot personer etter kjønn, alder og lovbruddsgruppe [Juveniles Charged for Sexual Offences]. National Statistics, Oslo.

[23] Mossige, S. (2000) Finnes forutsetninger i kulturen for at det skjer overgrep mot barn? I: Mossige, S.(red.): Personer som begår seksuelle overgrep mot barn. Forståelse, behandling og straff. Kunnskapsstatus og erfaringer fra de nordiske landene. TemaNord, 547.

[24] Butler, S.M. and Seto, M.C. (2002) Distinguishing Two Types of Adolescent Sex Offenders. Journal of the American Academy of Child \& Adolescent Psychiatry, 41, 83-90. https://doi.org/10.1097/00004583-200201000-00015

[25] Pullman, L.E., Leroux, E.J., Motayne, G. and Seto, M.C. (2014) Examining the Developmental Trajectories of Adolescent Sexual Offenders. Child Abuse \& Neglect, 38, 1249-1258. https://doi.org/10.1016/j.chiabu.2014.03.003

[26] Ronis, S.T. and Borduin, C.M. (2007) Individual, Family, Peer, and Academic Characteristics of Male Juvenile Sexual Offenders. Journal of Abnormal Child Psychology, 35, 153-163. https://doi.org/10.1007/s10802-006-9058-3

[27] Van Wijk, A., Loeber, R., Vermeiren, R., Pardini, D., Bullens, R. and Doreleijers, T. (2005) Violent Juvenile Sex Offenders Compared with Violent Juvenile Nonsex Offenders: Explorative Findings from the Pittsburgh Youth Study. Sexual Abuse: $A$ Journal of Research and Treatment, 17, 333-352. https://doi.org/10.1177/107906320501700306

[28] Seto, M.C. and Lalumiere, M.L. (2010) What Is So Special about Male Adolescent Sexual Offending? A Review and Test of Explanations through Meta-Analysis. Psychological Bulletin, 136, 526. https://doi.org/10.1037/a0019700

[29] O’Halloran, M., et al. (2002) Psychological Profiles of Sexually Abusive Adolescents in Ireland. Child Abuse \& Neglect, 26, 349-370. https://doi.org/10.1016/S0145-2134(02)00313-7

[30] Ward, T. and Siegert, R.J. (2002) Toward a Comprehensive Theory of Child Sexual Abuse: A Theory Knitting Perspective. Psychology, Crime and Law, 8, 319-351. https://doi.org/10.1080/10683160208401823

[31] Cantor, J.M., Blanchard, R., Robichaud, L.K. and Christensen, B.K. (2005) Quantitative Reanalysis of Aggregate Data on IQ in sexual Offenders. Psychological Bulletin, 131, 555-568. https://doi.org/10.1037/0033-2909.131.4.555

[32] Lindsay, W. (2002) Research and Literature on Sex Offenders with Intellectual and Developmental Disabilities. Journal of Intellectual Disability Research, 46, 74-85. https://doi.org/10.1046/j.1365-2788.2002.00006.x

[33] Beckett, R., Gerhold, C. and Brown, S. (2002) ASAP Adolescent Sexual Abuser Project. Child Abuser Assessment Schedule. Funded and Developed in Cooperation with SWAAY and the Oxford Mental Health Care NHS Trust.

[34] Malterud, K. (2012) Systematic Text Condensation: A Strategy for Qualitative Analysis. Scandinavian Journal of Public Health, 40, 795-805. https://doi.org/10.1177/1403494812465030

[35] Van Wijk, A.P., Mali, S. and Bullens, R.A. (2007) Juvenile Sex-Only and Sex-Plus Offenders An Exploratory Study on Criminal Profiles. International Journal of Offender Therapy and Comparative Criminology, 51, 407-419. https://doi.org/10.1177/0306624X06295436

[36] Hunter, J.A. and Becker, J.V. (1994) The Role of Deviant Sexual Arousal in Juvenile Sexual Offending Etiology, Evaluation, and Treatment. Criminal Justice and Be- 
havior, 21, 132-149. https://doi.org/10.1177/0093854894021001009

[37] Gannon, T.A. and Polaschek, D.L. (2006) Cognitive Distortions in Child Molesters: A Re-Examination of Key Theories and Research. Clinical Psychology Review, 26, 1000-1019. https://doi.org/10.1016/j.cpr.2005.11.010

[38] Gannon, T.A. and Rose, M.R. (2008) Female Child Sexual Offenders: Towards Integrating Theory and Practice. Aggression and Violent Behavior, 13, 442-461. https://doi.org/10.1016/j.avb.2008.07.002

[39] Ward, T., Gannon, T.A. and Keown, K. (2006) Beliefs, Values, and Action: The Judgment Model of Cognitive Distortions in Sexual Offenders. Aggression and Violent Behavior, 11, 323-340. https://doi.org/10.1016/j.avb.2005.10.003

[40] Finkelhor, D. (1984) Child Sexual Abuse: New Theory and Research. Free Press, New York

[41] Nøttestad, J.A., Bjørngaard, J.H. and Rasmussen, K. (2012) Oppvekstforhold, levekår og risikofaktorer for tilbakefall hos seksualforbrytere i fengsel: Skiller de seg fra øvrige innsatte? [Background Characteristics, Living Conditions and Risk Factors among Norwegian Sex Offenders in Prison]. Tidsskrift for Norsk Psykologforening, 49, 958-963.

[42] Dube, S.R., et al. (2001) Childhood Abuse, Household Dysfunction, and the Risk of Attempted Suicide throughout the Life Span: Findings from the Adverse Childhood Experiences Study. JAMA, 286, 3089-3096.

https://doi.org/10.1001/jama.286.24.3089

[43] Ward, T. and Beech, A.R. (2004) The Etiology of Risk: A Preliminary Model. Sexual Abuse: A Journal of Research and Treatment, 16, 271-284. https://doi.org/10.1177/107906320401600402

[44] Katsiyannis, A., Zhang, D., Barrett, D.E. and Flaska, T. (2004) Background and Psychosocial Variables Associated with Recidivism among Adolescent Males A 3 Year Investigation. Journal of Emotional and Behavioral Disorders, 12, 23-29. https://doi.org/10.1177/10634266040120010301

[45] Vermeiren, R., Schwab-Stone, M., Ruchkin, V., De Clippele, A. and Deboutte, D. (2002) Predicting Recidivism in Delinquent Adolescents from Psychological and Psychiatric Assessment. Comprehensive Psychiatry, 43, 142-149. https://doi.org/10.1053/comp.2002.30809

[46] Cortoni, F. and Marshall, W.L. (2001) Sex as a Coping Strategy and Its Relationship to Juvenile Sexual History and Intimacy in Sexual Offenders. Sexual Abuse: A Journal of Research and Treatment, 13, 27-43. https://doi.org/10.1177/107906320101300104

[47] Peter, J. and Valkenburg, P.M. (2008) Adolescents' Exposure to Sexually Explicit Internet Material, Sexual Uncertainty, and Attitudes toward Uncommitted Sexual Exploration Is There a Link? Communication Research, 35, 579-601. https://doi.org/10.1177/0093650208321754

[48] Seto, M.C., Cantor, J.M. and Blanchard, R. (2006) Child Pornography Offenses Are a Valid Diagnostic Indicator of Pedophilia. Journal of Abnormal Psychology, 115, 610. https://doi.org/10.1037/0021-843X.115.3.610

[49] Gudjonsson, G.H. (2003) The Psychology of Interrogations and Confessions: A Handbook. John Wiley \& Sons, Hoboken. 
Submit or recommend next manuscript to SCIRP and we will provide best service for you:

Accepting pre-submission inquiries through Email, Facebook, LinkedIn, Twitter, etc. A wide selection of journals (inclusive of 9 subjects, more than 200 journals)

Providing 24-hour high-quality service

User-friendly online submission system

Fair and swift peer-review system

Efficient typesetting and proofreading procedure

Display of the result of downloads and visits, as well as the number of cited articles Maximum dissemination of your research work

Submit your manuscript at: http://papersubmission.scirp.org/

Or contact jss@scirp.org 